\title{
Distribution and composition of Dragonfly and Damselfly species (Odonata) of the upper Rio das Velhas, Ouro Preto, Minas Gerais State, Brazil
}

\author{
Walter Francisco de Ávila Júnior ${ }^{1,3}$; Gustavo Lisboa Vieira Machado ${ }^{1,4}$; \\ Frederico Augusto de Atayde Lencioni ${ }^{2,5}$ \& Marco Antônio Alves Carneiro,
}

\footnotetext{
1 Universidade Federal de Ouro Preto (UFOP), Instituto de Ciências Exatas e Biológicas (ICEB), Departamento de Biodiversidade, Evolução e Meio Ambiente (DEBIO), Laboratório de Entomologia Ecológica. Ouro Preto, MG, Brasil.

2 Independent Researcher. Jacareí, SP, Brasil.

${ }^{3}$ ORCID: http://orcid.org/0000-0003-4707-0113. E-mail: walterfaj88@gmail.com

${ }^{4}$ ORCID: http://orcid.org/0000-0003-2059-9527. E-mail: gustavolvm@hotmail.com

${ }^{5}$ ORCID: http://orcid.org/0000-0002-3912-9181. E-mail: odonata@uol.com.br

${ }^{6}$ ORCID: http://orcid.org/0000-0003-3814-8118. E-mail: marco.carneiro@ufop.edu.br
}

\begin{abstract}
This paper describes the composition and distribution of Anisoptera and Zygoptera (0donata) species of the upper Rio das Velhas in the municipality of Ouro Preto, Minas Gerais State, Brazil. A total of 727 specimens of 40 species were collected near water bodies over a period of 23 months between 2015 and 2017. The families with greatest species richness were Libellulidae (13 species), Coenagrionidae (12 species) and Heteragrionidae and Aeshnidae (4 species each). Notable among the species collected were Perilestes fragilis Hagen in Selys, 1862, inhabiting well-preserved forests, Minagrion waltheri Santos, 1965, pertaining a endemic genus of Brazil and the recently described Heteragrion cauei Ávila-Júnior et al., 2017, and three species recorded for the first time for the state: Elasmothemis alcebiadesi (Santos, 1945), Erythrodiplax melanica Borror, 1942 and Erythrodiplax acantha Borror, 1942, the latter is considered Critically Endangered (CR) by the International Union for Conservation of Nature's (IUCN) Red List.
\end{abstract}

Key-Words. Anisoptera; Atlantic Forest; Damselfly; Richness; Zygoptera.

\section{INTRODUCTION}

Insects perform essential ecosystem services such as pollination, nutrient cycling and biological control (Costanza et al., 2017). Along with butterflies, beetles, locusts and ants, dragonflies (Anisoptera) and damselflies (Zygoptera), order Odonata, are one of the few insects familiar to the general public (Paulson, 2019). They are relatively large in size, have a high variety of coloring, and the larval stage is considered sedentary, living in a restricted area, and because of these biological issues they are sensitive to physical, chemical and biological changes of water, being used constantly as bioindicators of environmental quality (Corbet, 1999). Due to these characteristics (Odonata) arouses interest of both the general public and researchers. There are three extant suborders, Zygoptera (damselflies), Anisoptera (true dragonflies) and Anisozygoptera, however the latter is restricted to the Asia. Suborder
Zygoptera is known for its slender body size, separate eyes and weak flight, and Anisoptera features a more robust body size, most species with eyes close dorsally and a greater capacity for flight, although anisopteran species of Gomphidae and few other in Libellulidae the eyes are separated at the top of the head (Corbet, 1999; Garrison et al., 2006, 2010).

Odonata are conspicuous elements of freshwater systems where they account for a large proportion of biomass and energy transfer between trophic levels (Sanzone et al., 2003, Wittwer et al., 2010). As a species-rich group, with aquatic larvae and terrestrial adults, these organisms provide indications of environmental changes in both environments (Corbet, 1999; Carvalho et al., 2013; Monteiro-Júnior et al., 2013). In this way, Odonata respond rapidly to changes in the environment and are therefore frequently used in conservation studies and the evaluation of different impacts on the environment (Simaika \& Samways, 2012; 
Carvalho et al., 2013; Juen et al., 2014; Monteiro-Júnior et al., 2015). They are also voracious predators, both in the adult and larval stages, and thus potentially important in insect pest control (Samways \& Steytler, 1996). There are currently about of 900 species of Odonata known for Brazil (Pinto, 2020) being 269 of them registered for the state of Minas Gerais (Vilela et al., 2020a).

Ouro Preto is situated about $100 \mathrm{~km}$ from Belo Horizonte, the capital of the state of Minas Gerais, Southeastern Brazil. It is a historical city known worldwide for its architecture and its central role in the gold cycle of the $18^{\text {th }}$ century, having been recognized as a UNESCO World Heritage Site in 1980 (Sorgine, 2008). Herein we present the first checklist of species of Odonata found in the upper Rio das Velhas in the municipality of Ouro Preto.

\section{MATERIAL AND METHODS}

\section{Study Area}

The work was carried out in the region of the Parque Natural Municipal da Cachoeira das Andorinhas (PNMCA) and its vicinity, from Fazenda da Brígida, owned by Universidade Federal de Ouro Preto, to the district of Catarina Mendes, both located within the Área de Proteção Ambiental (Environmental Protection Area) Cachoeira das Andorinhas (APA Cachoeira das Andorinhas). After the creation of PNMCA in 2005, a new law was approved by municipal administration proposing a new delimitation of the park, which was sanctioned by law № 69/05 establishing its current limits encompassing a total of 557 hectares.

PNMCA is situated at the source of Rio das Velhas, in the southeastern region of the mosaic of conservation units of APA Cachoeira das Andorinhas in the municipality of Ouro Preto. Collecting sites numbered 1, 2, 3, 5, 9 and 10 have an average width of $3 \mathrm{~m}$ in length and a depth ranging from $20-30 \mathrm{~cm}$, sites $4,6,7$, and 8 have an average width of $1.5 \mathrm{~m}$ with a depth ranging between 10-30 cm, however, both sites feature some kind of semi-lentic systems, forming pools up to $1.5 \mathrm{~m}$ deep. The PNMCA Region had a predominance of seasonal semide-

Table 1. Sampling locations of Odonata in the upper Rio das Velhas, Parque Natural Municipal Cachoeira das Andorinhas, Ouro Preto Municipality, Minas Gerais State, Brazil, indicating the name, geographical coordinates and altitude.

\begin{tabular}{cllll}
\hline \multirow{2}{*}{ Sites } & \multicolumn{1}{c}{ Name } & \multicolumn{2}{c}{ Coordinates } & \multirow{2}{*}{ Altitude (m a.s.I.) } \\
\cline { 3 - 4 } & & $20^{\circ} 19^{\prime} 59.24^{\prime \prime} S$ & $43^{\circ} 30^{\prime} 59.89^{\prime \prime} \mathrm{W}$ & 1080 \\
\hline P1 & Rio das Velhas & $20^{\circ} 20^{\prime} 3.67^{\prime \prime} S$ & $43^{\circ} 30^{\prime} 39.03^{\prime \prime} \mathrm{W}$ & 1083 \\
P2 & Rio das Velhas & $20^{\circ} 20^{\prime} 41.97^{\prime \prime} \mathrm{S}$ & $43^{\circ} 29^{\prime} 55.94^{\prime \prime} \mathrm{W}$ & 1082 \\
P3 & Rio das Velhas & $20^{\circ} 20^{\prime} 54.62^{\prime \prime} \mathrm{S}$ & $43^{\circ} 29^{\prime} 43.70^{\prime \prime} \mathrm{W}$ & 1102 \\
P4 & Undefined & $20^{\circ} 20^{\prime} 52.5^{\prime \prime} \mathrm{S}$ & $43^{\circ} 29^{\prime} 38.7^{\prime \prime} \mathrm{W}$ & 1106 \\
P5 & Rio das Velhas & $20^{\circ} 20^{\prime} 28.95^{\prime \prime} \mathrm{S}$ & $43^{\circ} 30^{\prime} 38.43^{\prime \prime} \mathrm{W}$ & 1109 \\
P6 & São Bartolomeu Stream & 1311 \\
P7 & Undefined & $20^{\circ} 22^{\prime} 19.64^{\prime \prime} \mathrm{S}$ & $43^{\circ} 29^{\prime} 29.36^{\prime \prime} \mathrm{W}$ & 1277 \\
P8 & Rio das Velhas & $20^{\circ} 21^{\prime} 53.20^{\prime \prime} \mathrm{S}$ & $43^{\circ} 29^{\prime} 30.43^{\prime \prime} \mathrm{W}$ & 1205 \\
P9 & Rio das Velhas & $20^{\circ} 21^{\prime} 35.28^{\prime \prime} \mathrm{S}$ & $43^{\circ} 29^{\prime} 18.00^{\prime \prime} \mathrm{W}$ & 120 \\
P10 & Rio das Velhas & $20^{\circ} 21^{\prime} 2.42^{\prime \prime} \mathrm{S}$ & $43^{\circ} 29^{\prime} 24.01^{\prime \prime} \mathrm{W}$ & 1110 \\
\hline
\end{tabular}

ciduous forest in the Atlantic Forest domain (Scalco \& Gontijo, 2011). The sampling sites coordinates and altitude can be found in the Table 1 .

\section{Collecting and Specimen Curation}

Surveys were conducted bi-weekly over a period of 23 months between April 2015 and March 2017, with some campaigns being cancelled due to bad weather resulting in a total of 27 field campaigns. Ten sample sites were defined along Rio das Velhas and its main tributaries (Fig. 1). Odonates were collected near water bodies at each sampling point during random walks of 1 hour between 10:00h and 15:00h, the hottest period of the day (De Marco-Jr. \& Resende, 2002; Juen et al., 2014). The specimens were collected with the aid of an aerial entomological nets, with adults being packed and conditioned following the recommendations of Lencioni (2017). The collected specimens were deposited in the Coleção Entomológica of the Laboratório de Entomologia Ecológica of Universidade Federal de Ouro Preto (UFOP). The collections were performed with the authorization of the Instituto Estadual de Florestas - MG (IEF № 039/2016).

\section{Statistical Analysis}

Collector and rarefaction curves (interpolation) were generated to verify efficiency of the sampling effort. The ACE (abundance coverage estimator) and CHAO estimators were used to estimate the number of species in the region following the routine proposed in the packages "vegan" and "BiodiversityR" (Kindt \& Coe, 2005; Oksanen et al., 2018) of the program R (R Core Team, 2019). Rare species were considered those that had only 1 or 2 individuals in the total sample, or "singleton" and "doubleton" species, respectively; and species recorded in only 1 or 2 samples, or "unicate" or "duplicate" species, respectively.

\section{RESULTS}

A total of 727 individuals of 40 species were captured, with 21 being of the suborder Zygoptera and 19 of the suborder Anisoptera (Table 2, Figs. 2 and 3). The most species-rich Zygoptera families were Coenagrionidae (12 species) and Heteragrionidae (4 species), while the most species-rich Anisoptera families were Libellulidae (13 species) and Aeshnidae (4 species).

Among the registered species, 11 (27,5\%) were "singletons", and 5 (12,5\%) "doubletons". Sixteen species were considered as "unicates", and seven species as "duplicates" (Table 2). The most abundant species were Hetaerina longipes Hagen in Selys, 1853 with 156 individuals (21.5\%), and Argia sordida Hagen in Selys, 1865, with 138 individuals (19.0\%).

The collector curves did not stabilize, suggesting that sampling effort was not sufficient to register a represen- 
Table 2. List of Odonata species collected at the source of Rio das Velhas, in APA Cachoeira das Andorinhas and Parque Natural Municipal Cachoeira das Andorinhas in Ouro Preto, Minas Gerais State, Brazil. (S) Singleton; (D) Doubleton; (1) Presence, (0) Absence. IUCN Status: (DD) Data Deficient, (CR) Critically Endangered, (LC) Least Concern; $\left({ }^{*}\right)$ first record for Minas Gerais State.

\begin{tabular}{|c|c|c|c|c|c|c|c|c|c|c|c|c|c|}
\hline \multirow{2}{*}{ Taxon } & \multicolumn{2}{|c|}{ Sample } & \multirow{2}{*}{$\begin{array}{l}\text { IUCN } \\
\text { status }\end{array}$} & \multicolumn{10}{|c|}{ Sites } \\
\hline & $s$ & D & & P1 & $\mathbf{P 2}$ & P3 & P4 & P5 & P6 & P7 & P8 & P9 & $\mathbf{P} 10$ \\
\hline \multicolumn{14}{|l|}{ Zygoptera } \\
\hline \multicolumn{14}{|l|}{ Perilestidae } \\
\hline Perilestes fragilis Hagen in Selys, 1862 & $x$ & & DD & 0 & 1 & 0 & 0 & 0 & 0 & 0 & 0 & 0 & 0 \\
\hline \multicolumn{14}{|l|}{ Calopterygidae } \\
\hline Hetaerina longipes Hagen in Selys, 1853 & & & DD & 1 & 1 & 0 & 1 & 1 & 1 & 0 & 0 & 0 & 0 \\
\hline Hetaerina simplex Selys, 1853 & $x$ & & DD & 0 & 0 & 0 & 1 & 1 & 0 & 0 & 0 & 0 & 0 \\
\hline Mnesarete guttifera (Selys, 1873) & & & $\mathrm{LC}$ & 1 & 1 & 0 & 1 & 1 & 1 & 0 & 0 & 0 & 0 \\
\hline \multicolumn{14}{|l|}{ Megapodagrionidae } \\
\hline Allopodagrion contortum (Hagen in Selys, 1862) & & & $\mathrm{LC}$ & 0 & 1 & 0 & 1 & 0 & 0 & 0 & 0 & 0 & 0 \\
\hline \multicolumn{14}{|l|}{ Heteragrionidae } \\
\hline Heteragrion cauei Ávila-Júnior et al., 2017 & & & DD & 1 & 1 & 0 & 1 & 1 & 0 & 0 & 0 & 0 & 1 \\
\hline Heteragrion rogertaylori Lencioni, 2013 & & & DD & 0 & 0 & 0 & 1 & 1 & 0 & 0 & 0 & 0 & 0 \\
\hline Heteragrion gracile Machado, 2006 & $x$ & & DD & 0 & 0 & 0 & 0 & 0 & 1 & 0 & 0 & 0 & 0 \\
\hline Heteragrion sp. & $x$ & & & 0 & 0 & 0 & 0 & 1 & 0 & 0 & 0 & 0 & 1 \\
\hline \multicolumn{14}{|l|}{ Coenagrionidae } \\
\hline Acanthagrion gracile (Rambur, 1842) & & & DD & 0 & 0 & 1 & 0 & 0 & 0 & 0 & 0 & 0 & 0 \\
\hline Argia claussenii Selys, 1865 & & & DD & 1 & 1 & 0 & 1 & 1 & 0 & 0 & 0 & 0 & 0 \\
\hline Argia croceipennis Selys, 1865 & & & $\mathrm{LC}$ & 1 & 1 & 0 & 1 & 1 & 0 & 0 & 0 & 0 & 0 \\
\hline Argia lilacina Selys, 1865 & & $x$ & DD & 1 & 1 & 0 & 1 & 1 & 0 & 0 & 0 & 0 & 0 \\
\hline Argia reclusa Selys, 1865 & & & DD & 1 & 1 & 0 & 1 & 1 & 0 & 0 & 0 & 0 & 0 \\
\hline Argia smithiana Calvert, 1909 & & $x$ & DD & 1 & 1 & 0 & 1 & 1 & 0 & 0 & 0 & 0 & 0 \\
\hline Argia sordida Hagen in Selys, 1865 & & & DD & 1 & 1 & 0 & 1 & 1 & 0 & 0 & 1 & 1 & 1 \\
\hline Ischnura capreolus (Hagen, 1861) & & & DD & 0 & 0 & 1 & 0 & 0 & 0 & 0 & 0 & 0 & 0 \\
\hline Minagrion waltheri Santos, 1965 & & $x$ & DD & 0 & 0 & 1 & 0 & 0 & 0 & 0 & 0 & 0 & 0 \\
\hline Oxyagrion basale Selys, 1876 & & & $\mathrm{DD}$ & 0 & 0 & 1 & 0 & 0 & 0 & 0 & 1 & 0 & 0 \\
\hline Oxyagrion terminale Selys 1876 & & & DD & 0 & 0 & 1 & 0 & 0 & 0 & 0 & 0 & 0 & 0 \\
\hline Telebasis carmesina Calvert, 1909 & $x$ & & $\mathrm{LC}$ & 0 & 0 & 1 & 0 & 0 & 0 & 0 & 0 & 0 & 0 \\
\hline \multicolumn{14}{|l|}{ Anisoptera } \\
\hline \multicolumn{14}{|l|}{ Aeshnidae } \\
\hline Castoraeschna colorata (Martin, 1908) & & & DD & 0 & 0 & 1 & 0 & 0 & 0 & 0 & 0 & 0 & 0 \\
\hline Castoraeschna margarethae Jurzitza, 1979 & & $x$ & DD & 0 & 0 & 1 & 0 & 0 & 0 & 0 & 0 & 0 & 0 \\
\hline Coryphaeschna perrensi (Mclachlan, 1887) & & & DD & 0 & 0 & 1 & 0 & 0 & 0 & 0 & 0 & 0 & 0 \\
\hline Rhionaeschna planaltica (Calvert, 1952) & $x$ & & $\mathrm{LC}$ & 0 & 0 & 1 & 0 & 0 & 0 & 0 & 0 & 0 & 0 \\
\hline \multicolumn{14}{|l|}{ Gomphidae } \\
\hline Progomphus complicatus Selys, 1854 & & & $\mathrm{LC}$ & 1 & 1 & 0 & 0 & 1 & 0 & 0 & 0 & 0 & 0 \\
\hline Zonophora campanulata machadoi St. Quentin, 1973 & $x$ & & DD & 1 & 0 & 0 & 0 & 0 & 0 & 0 & 0 & 0 & 0 \\
\hline \multicolumn{14}{|l|}{ Libellulidae } \\
\hline Dasythemis mincki mincki (Karsch, 1889) & & $x$ & DD & 0 & 0 & 1 & 0 & 0 & 0 & 0 & 0 & 0 & 0 \\
\hline Elasmothemis alcebiadesi (Santos, 1954)* & & & DD & 1 & 1 & 0 & 1 & 1 & 0 & 0 & 0 & 0 & 0 \\
\hline Erythrodiplax acantha Borror, 1942* & & & $C R$ & 0 & 0 & 1 & 0 & 0 & 0 & 0 & 0 & 0 & 0 \\
\hline Erythrodiplax fusca (Rambur, 1842) & & & $\mathrm{LC}$ & 0 & 0 & 1 & 0 & 0 & 0 & 0 & 0 & 0 & 0 \\
\hline Erythrodiplax melanica Borror, $1942^{*}$ & & & DD & 0 & 0 & 1 & 0 & 0 & 0 & 0 & 0 & 0 & 0 \\
\hline Macrothemis heteronycha (Calvert, 1909) & $x$ & & $\mathrm{LC}$ & 0 & 0 & 1 & 0 & 0 & 0 & 0 & 0 & 0 & 0 \\
\hline Macrothemis tenuis Hagen, 1868 & & & $\mathrm{LC}$ & 1 & 1 & 0 & 1 & 1 & 0 & 1 & 0 & 1 & 1 \\
\hline Macrothemis declivata Calvert, 1909 & & & DD & 1 & 1 & 0 & 1 & 1 & 0 & 1 & 0 & 1 & 1 \\
\hline Macrothemis imitans imitans Karsch, 1890 & & & DD & 1 & 1 & 0 & 1 & 1 & 0 & 0 & 0 & 0 & 0 \\
\hline Micrathyria athenais Calvert, 1909 & $x$ & & DD & 0 & 0 & 1 & 0 & 0 & 0 & 0 & 0 & 0 & 0 \\
\hline Orthemis discolor (Busmeister, 1839) & $x$ & & $\mathrm{LC}$ & 0 & 0 & 1 & 0 & 0 & 0 & 0 & 0 & 0 & 0 \\
\hline Pantala flavescens (Fabricius, 1798) & & & $\mathrm{LC}$ & 1 & 1 & 1 & 0 & 0 & 0 & 0 & 0 & 0 & 0 \\
\hline Tramea binotata (Rambur, 1842) & $x$ & & DD & 0 & 0 & 1 & 0 & 0 & 0 & 0 & 0 & 0 & 0 \\
\hline
\end{tabular}




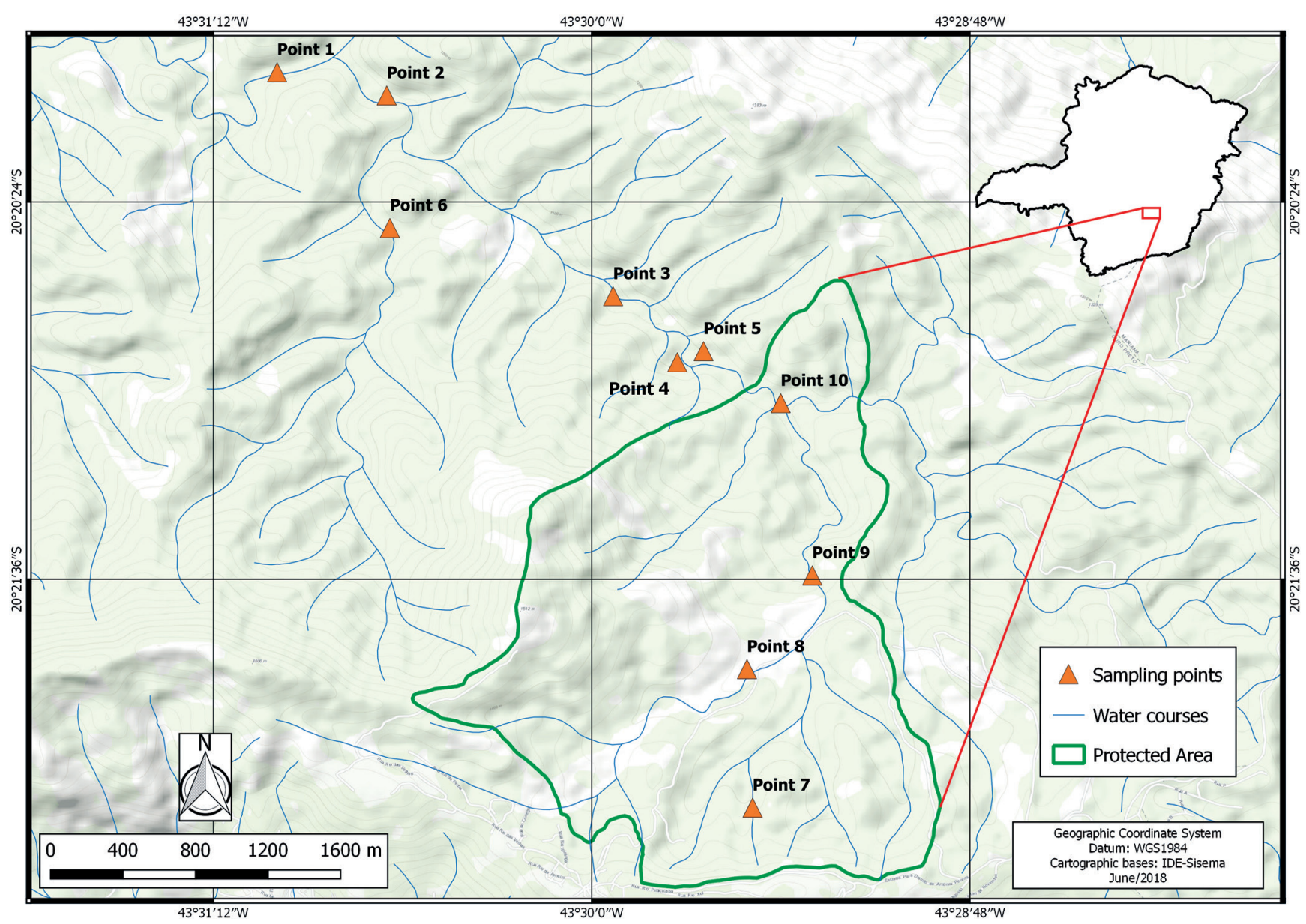

Figure 1. Map showing the sampled sites in the, Parque Natural Municipal Cachoeira das Andorinhas (green line), Ouro Preto Municipality, Minas Gerais State, Brazil.

tative number the species of dragonflies of the region (Fig. 4). The number of species sampled (40) corresponded to $78 \%$ of the species estimated by ACE (51 species) and $81 \%$ of the species estimated by CHAO (49 species).

\section{DISCUSSION}

The higher number of species of Coenagrionidae and Libellulidae sampled here reflects their dominance in Brazil and other regions of the world (e.g., Dijkstra \& Clausnitzer, 2006; Bedê et al., 2015; Souza et al., 2017; Vilela et al., 2020a). Dijkstra \& Clausnitzer (2006) stated that these two families are numerically dominant because they are evolutionary and adapted better to unstable habitats than other families of Odonata, however, other factors may influence the sampling of other families, such as: difficulty in capturing due to the high capacity for vagility, habits that are still unknown as noted in Souza et al. (2017).

Some of the recorded species, of special interest, are briefly commented below. Perilestes fragilis Hagen in Selys, 1862 are frequently found in forests in a good state of conservation (Lencioni, 2005). Minagrion waltheri (Selys, 1876) (Fig. 3g), belongs to a genus endemic to Brazil and the knowledge of its distribution is associat-

Table 3. Comparison of the number of species, abundance of individuals and sampling effort between published works for the Minas Gerais State, Brazil.

\begin{tabular}{|c|c|c|c|c|}
\hline Site & № of species & Abundance of individuals & Sampling effort & Reference \\
\hline Serra de São José & 128 & No data & 16 years & Bedê et al., 2015 \\
\hline West of Minas Gerais & 90 & No data & 8 years & Vilela et al., 2020 \\
\hline Bueno Brandão & 71 & No data & 35 fieldwork; 1 year & Amorim et al., 2018 \\
\hline Poços de Caldas & 58 & 720 & 3 years & Santos, 1966 \\
\hline Mata do Baú-Barroso & 57 & No data & 26 fieldwork; 1 year and 3 months & Souza et al., 2013 \\
\hline Refúgio da Vida Silvestre do Rio Pandeiros & 48 & 97 & 20 fieldwork; 160 hours & Souza et al., 2017 \\
\hline Reservatório Sucupira-Uberlândia & 43 & 860 & 4 sections ( 2 dry season) and ( 2 rainy season) & Barbosa et al., 2019 \\
\hline Rio das Velhas - Ouro Preto & 40 & 727 & 27 fieldwork; 2 years & Present study \\
\hline Triangulo Mineiro & 36 & 860 & 4 months & Borges et al., 2019 \\
\hline Uberlândia & 31 & No data & 1 year & Vilela et al., 2016 \\
\hline PARNA Serra do Cipó & 27 & 115 & 2 years & Almeida et al., 2013 \\
\hline
\end{tabular}




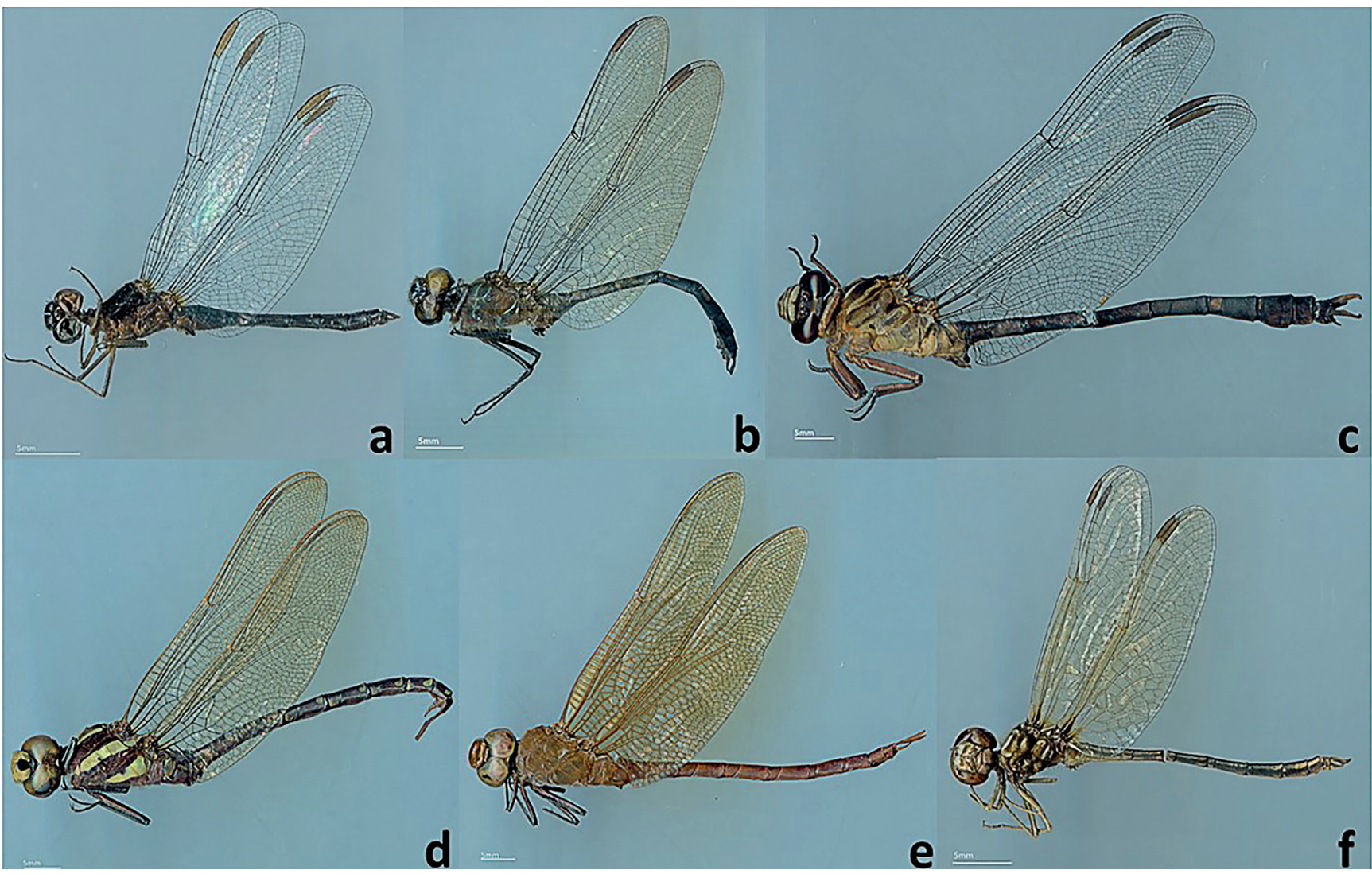

Figure 2. Some species of the suborder Anisoptera collected in the upper Rio das Velhas, Parque Natural Municipal Cachoeira das Andorinhas, Ouro Preto Municipality, Minas Gerais State, Brazil: (a) Erythrodiplax acantha, (b) Elasmothemis alcebiadesi, (c) Zonophora campanulata machadoi, (d) Castoraeschna colorata, (e) Coryphaeschna perrensi and (f) Macrothemis heteronycha.

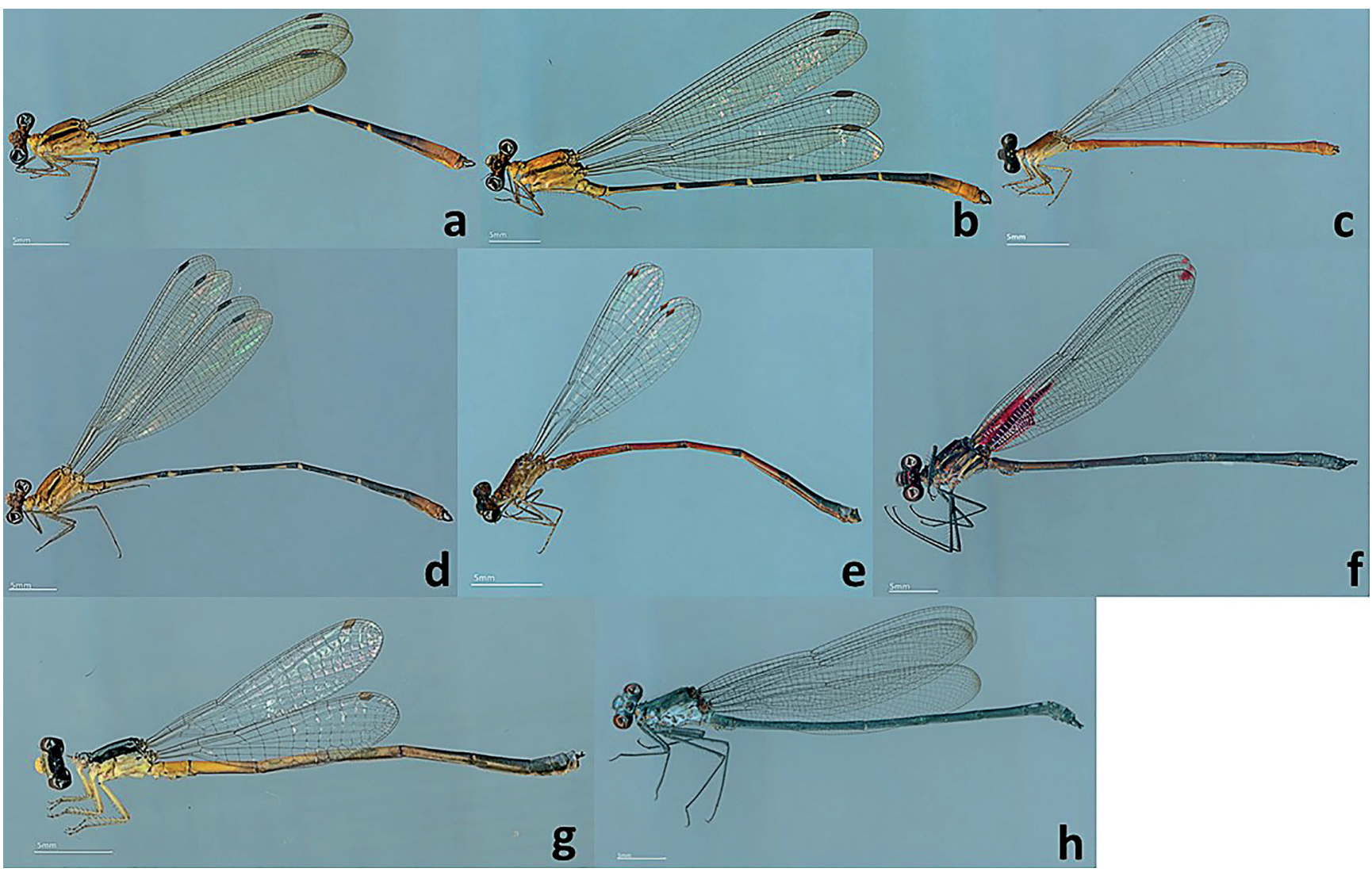

Figure 3. Some species of the suborder Zygoptera collected in the upper Rio das Velhas, Parque Natural Municipal Cachoeira das Andorinhas, Ouro Preto Municipality, Minas Gerais State, Brazil: (a) Heteragrion cauei, (b) Heteragrion rogertaylori, (c) Telebasis carmesina, (d) Heteragrion gracile, (e) Oxyagrion basale, (f) Hetaerina longipes, (g) Minagrion waltheri and (h) Mnesarete guttifera. 

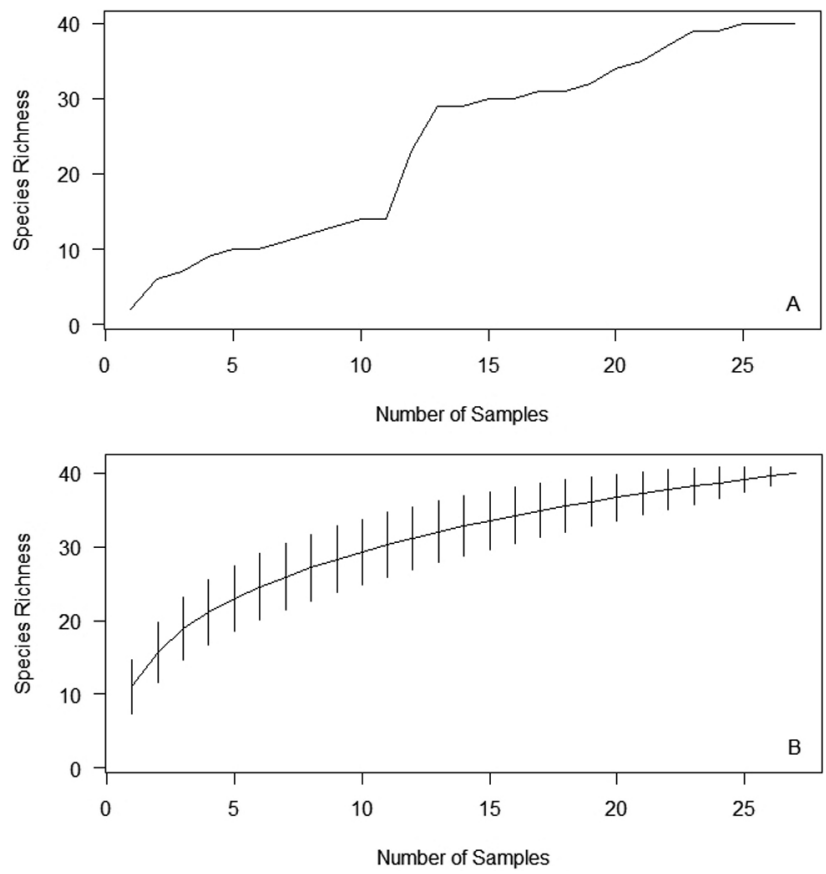

Figure 4. Odonata species accumulation curves: (A) collector method; (B) rarefaction curve. (vertical bars represent \pm 2 standard deviations).

ed with preserved areas (Vilela et al., 2020b). Individuals of four species of Heteragrion Selys, 1862 were collected, including the recently described Heteragrion cauei ÁvilaJúnior et al., 2017 (Figs. 3a and 5). Species of this genus are generally considered bioindicators of environmental quality, where the presence of established populations indicates low man-impacted environments (Machado, 1988; Monteiro-Júnior et al., 2015). Heteragrion cauei was collected in stretches of the best-preserved ciliary forests of Rio das Velhas, downstream from the Véu da Noiva waterfall to the bridge in the district of Catarina Mendes (sampling points 1-6 and 10; Fig. 1; see also Ávila-Júnior et al., 2017). Three new records for the state of Minas Gerais are highlighted: Elasmothemis alcebiadesi Santos, 1945 (Fig. 2b) is recorded only São Paulo State (Costa et al., 2000); Erythrodiplax melanica Borror, 1942 with recorded only to Tocantins and Pará States (Cortês et al., 2011; Pinto \& Carvalho, 2009) and Erythrodiplax acantha Borror, 1942 (Fig. 2a) recorded for São Paulo and Goiás States (Costa et al., 2000; Dutra \& De Marco-Jr., 2015), being the latter in Critically Endangered (CR) status with extremely high risk of extinction in the wild (IUCN, 2020).

Compared to other studies conducted in the Minas Gerais, the present survey has a significant number of recorded species (Table 3). The number found in this study (40 species) is within the confidence interval of the mean $($ Mean $=56.55 ; \mathrm{Cl}[36.17,76.92])$ of the longer periods sampled (Bedê et al., 2015; Vilela et al., 2020a). However, the number of species found here was lower than the average of other studies and may be reflect the climatic conditions at Ouro Preto mountain region. According to Köppen \& Geiger (1928), the climate of Ouro Preto is characterized as Cwb: (humid temperate climate with dry winter and temperate summer). In the mountaintop regions of the meridional portion of Southeastern Brazil, rainy days are accompanied by a drop in tempera-

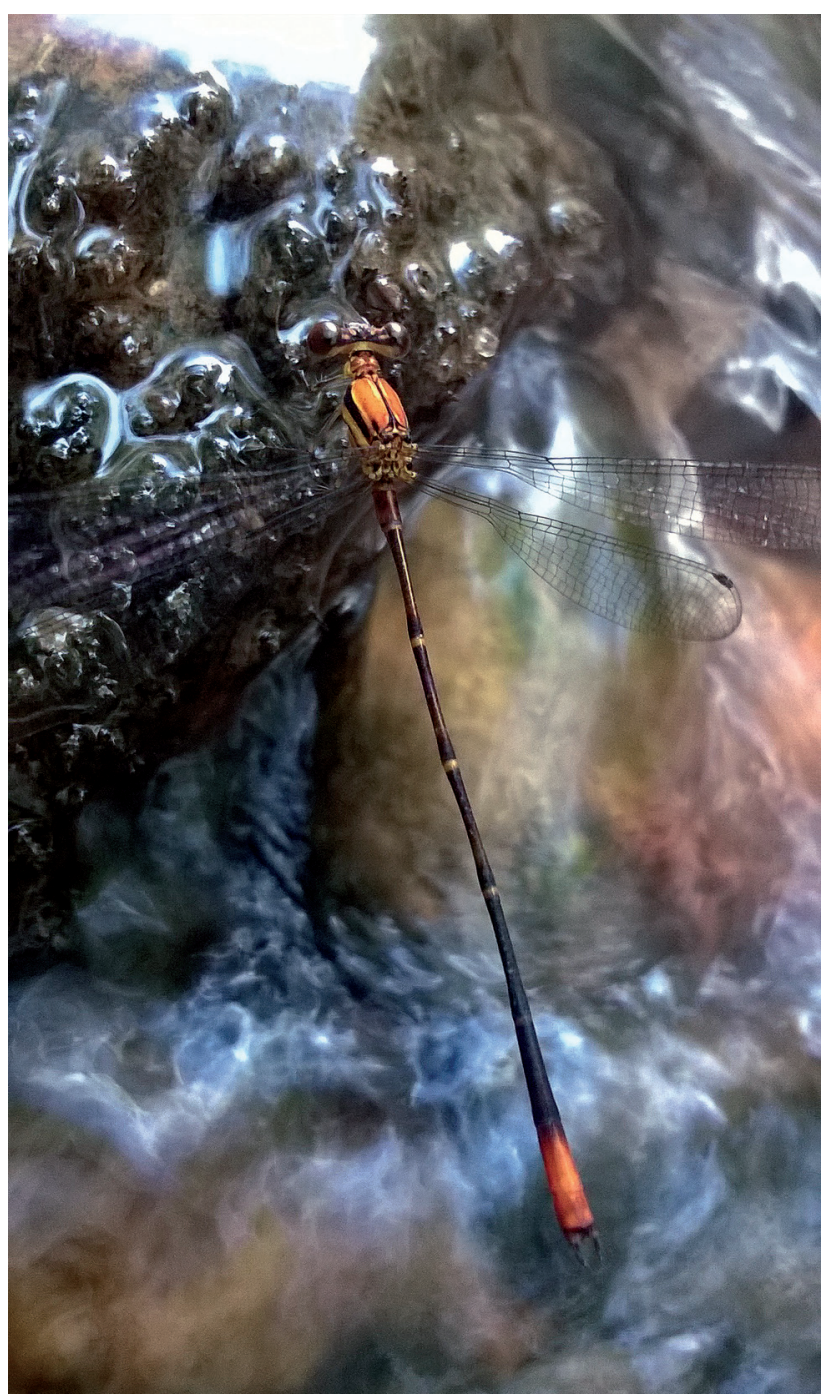

Figure 5. Dorsolateral view of live individual of Heteragrion cauei Ávila-Júnior et al., 2017 in life. Photo: W.F. Ávila-Júnior.

ture even in the summer. Many of the field trips had to be canceled due to rain or heavy fog, which is typical of the Ouro Preto. Thus, it is still necessary a larger and longer period sample to better characterize the diversity of Odonata species in the Ouro Preto region.

The species considered rare in the present study may not necessarily be rare in nature, but rather just in the sample. Some of such species may be considered specialists with low populations levels, generalists or tourist species (Schoener, 1987; Novotný \& Basset, 2000; Longino et al., 2002). In addition, greater sampling effort or the use of other collection methodologies should be employed as they may present a different scenario in relation to the abundance of these species (Almeida et al., 2013; Souza et al., 2017).

\section{CONCLUSION}

The presence of the aforementioned significant species suggests that PNMCA has well-preserved stretches and that study of peri-urban areas would be importance to biodiversity conservation. The continuation Odonata 
sampling in the region in the coming years should increase the number, in addition, we encourage further study in areas not yet sampled.

\section{ACKNOWLEDGEMENTS}

We thank anonymous reviewers for their comments on a previous version of the manuscript, Prof. Dr. Angelo Barbosa M. Machado in memorian (UFMG) and Prof. Dr. Ângelo Parise Pinto (UFPR) for help to identify some Anisoptera. Financial support was provided by Universidade Federal de Ouro Preto (UFOP) by the Scientific Initiation program (PIP-2S/UFOP). Logistical support and licenses were provided by UFOP, Instituto Estadual de Florestas de Minas Gerais (IEF) and Instituto Chico Mendes de Conservação da Biodiversidade (ICMBio).

\section{AUTHORS' CONTRIBUTIONS}

Contribution to the study design (WFAJ \& MAAC), contribution to the data collection (WFAJ, MAAC \& GLVM), contribution to the species identification (WFAJ \& FAAL), contribution to the statistical analysis (MAAC \& WFAJ), partial funding contribution from the study (MAAC \& WFAJ) and contribution to the critical review study (WFAJ, MAAC, FAAL \& GLVM).

\section{REFERENCES}

Almeida, M.V.O.; Pinto, A.P.; Carvalho, A.L. \& Takiya, D.M. 2013. When rare is just a matter of sampling: unexpected dominance of clubtail dragonflies (Odonata, Gomphidae) through different collecting methods at Parque Nacional da Serra do Cipó, Minas Gerais State, Brazil. Revista Brasileira de Entomologia, 57(4): 417-423.

Amorim, M.S.; Souza, M.M. \& Anjos, C.S. 2018. Riqueza de libélulas (Insecta: Odonata) no município de Bueno Brandão, sul de Minas Gerais. MG BIOTA, Belo Horizonte, 11(1): 16-32.

Ávila-Júnior, W.F.; Lencioni, F.A.A. \& Carneiro, M.A.A. 2017. Heteragrion cauei sp. nov., a new damselfly from Minas Gerais, Brazil (0donata: Heteragrionidae). Odonatologica, 46(3/4): 275-286.

Barbosa, M.S.; Borges, L.R.; Vilela, D.S.; Venâncio, H. \& Santos, J.C. 2019. Odonate communities of the Sucupira reservoir rio Uberabinha, Minas Gerais, Brazil. Papéis Avulsos de Zoologia, 59(22): 1-10.

Bedê, L.C.; Machado, A.B.M.; Piper, W. \& Souza, M.M. 2015. Odonata of the Serra de São José - Brazil's first Wildlife Reserve aimed at the conservation of dragonflies. Notulae odonatologicae, 8(5): 117-128.

Borges, L.R.; Barbosa, M.S.; Carneiro, M.A.A.; Vilela, D.S. \& Santos, J.C. 2019. Dragonflies and damselflies (Insecta: Odonata) from a Cerrado area at Triângulo Mineiro, Minas Gerais, Brazil. Biota Neotropica, 19(1): 1-10.

Carvalho, F.G.; Pinto, N.S.; Oliveira-Júnior, J.M.B. \& Juen, L. 2013. Effects of marginal vegetation removal on Odonata communities. Acta Limnologica Brasiliensia, 25(1): 10-18.

Corbet, P.S. 1999. Dragonflies: behavior and ecology of Odonata. Ithaca, Cornell University Press.

Cortês, L.G.; Almeida, M.C.; Pinto, N.S. \& De Marco-Jr., P. 2011. Fogo em Veredas: Avaliação de Impactos sobre Comunidades de Odonata (Insecta). Biodiversidade Brasileira, 1(2): 128-145.
Costa, J.M.; Machado, A.B.M.; Lencioni, F.A.A. \& Santos, T.C. 2000. Diversidade e distribuição dos Odonata (Insecta) no Estado de São Paulo, Brasil: parte 1 - lista de espécies e registro bibliográficos. Publicações Avulsas do Museu Nacional, Rio de Janeiro, 80: 1-27.

Costanza, R.; de Groot, R.; Braat, L.; Kubiszewski, I.; Fioramonti, L.; Sutton, P.; Farber, S. \& Grasso, M. 2017. Twenty years of ecosystem services: How far have we come and how far do we still need to go? Ecosystem Services, 28: 1-16.

De Marco-Jr., P. \& Resende, D.C. 2002. Activity patterns and thermoregulation in a tropical dragonfly assemblage. Odonatologica, 31: 129-138.

Dijkstra, K.D.B. \& Clausnitzer, V. 2006. Thoughts from Africa: how can forest influence species composition, diversity and speciation in tropical Odonata. In: Rivera, A.C. (Ed.). Forest and Dragonflies. Fourth WDA International Symposium of Odonatology. Sofia, Pensoft Publishers. p. 127-151.

Dutra, S. \& De Marco-Jr., P. 2015. Bionomic differences in odonates and their influence on the efficiency of indicator species of environmental quality. Ecological Indicators, 49: 132-142.

Garrison, R.W.; von Ellenrieder, N. \& Louton, J.A. 2006. Dragonfly Genera of the New World. Baltimore, The Johns Hopkins University Press.

Garrison, R.W.; von Ellenrieder, N. \& Louton, J.A. 2010. Damselfly Genera of the New World. Baltimore, The Johns Hopkins University Press.

International Union for Conservation of Nature and Natural Resources (IUCN). 2020. The IUCN Red List of Threatened Species. Version 2020-1. Available: https://www.iucnredlist.org. Access: 22/04/2020.

Juen, L.; Oliveira-Júnior, J.M.B. \& Shimano, Y. 2014. Composição e riqueza de odonata (Insecta) em riachos com diferentes níveis de conservação em um ecótone Cerrado-Floresta Amazônica. Acta Amazonica, 44: 175-184.

Kindt, R. \& Coe, R. 2005. Tree diversity analysis. A manual and software for common statistical methods for ecological and biodiversity studies. Nairobi, World Agroforestry Centre (ICRAF).

Köppen, W. \& Geiger, R. 1928. Die klimate der Erde. Gotha, Verlag Justus Perthes. (Wall-map $150 \mathrm{~cm} \times 200 \mathrm{~cm}$ ).

Lencioni, F.A.A. 2005. The Damselflies of Brazil: An Illustrated Identification Guide 1 - The Non-Coenagrionidae families. São Paulo, All Print Editora.

Lencioni, F.A.A. 2017. Damselflies of Brazil an illustrated identification guide Southeast region. [electronic book]. Jacareí, São Paulo, Edition of author.

Longino, J.T.; Coddington, J.A. \& Colwell, R.K. 2002. The ant fauna of a tropical rain forest: estimating species richness three different ways. Ecology, 83(3): 689-702.

Machado, A.B.M. 1988. Heteragrion petiense spec. nov., from de state of Minas Gerais, Brazil (Zygoptera: Megapodagrionidae). Odonatologica, 17: 267-274.

Monteiro-Júnior, C.D.S.; Couceiro, S.R.M.; Hamada, N. \& Juen, L. 2013. Effect of vegetation removal for road building on richness and composition of Odonata communities in Amazonia, Brazil. International Journal of Odonatology, 17: 1-13.

Monteiro-Júnior, C.D.S.; Juen, L. \& Hamada, N. 2015. Analysis of urban impacts on aquatic habitats in the central Amazon basin: Adult odonates as bioindicators of environmental quality. Ecological Indicators, 48: 303-311.

Novotný, V. \& Basset, Y. 2000. Rare species in communities of tropical insect herbivores: pondering the mystery of singletons. OIKOS, 89: 564-572.

Oksanen, J.; Blanchet, F.G.; Friendly, M.; Kindt, R.; Legendre, P.; McGlinn, D.; Minchin, P.R.; O'Hara, R.B.; Simpson, G.L.; Solymos, P.; Stevens, M.H.H.; Szoecs, E. \& Wagner, H. 2018. Vegan, Community Ecology Package. R package version 2.5-2. https://CRAN.R-project.org/package=vegan.

Paulson, D. 2019. Dragonflies \& Damselflies: a natural history. Brighton, Ivy Press.

Pinto, A.P. 2020. Odonata. In: Catálogo Taxonômico da Fauna do Brasil. PNUD. Available: http://fauna.jbrj.gov.br/fauna/faunadobrasil/171. Access: 30/09/2020. 
Pinto, A.P. \& Carvalho, A.L. 2009. On a small collection of Dragonflies from Barcarena Municipality, Pará State, Brazil, with the Rediscovery of Acanthallagma luteum Williamson \& Williamson. Bulletin of American Odonatology, 11(1): 11-16.

Samways, M.J. \& Steytler, N.S. 1996. Dragonfly (Odonata) distribution patterns in urban and forest landscapes, and recommendations for riparian management. Biological Conservation, 78: 279-288.

Santos, N.D. 1966. Odonatos da região de Poços de Caldas, Minas Gerais. Atlas da Sociedade de Biologia do Rio de Janeiro, do Rio de Janeiro, 10: 65-68.

Sanzone, D.M; Meyer, J.L.; Marti, E.; Gardiner, E.P.; Tank, J.L. \& Grimm, B.N. 2003. Carbon and nitrogen transfer from a desert stream to riparian predators. Oecologia, 134: 238-250.

Scalco, R.F. \& Gontijo, B.M. 2011. Paradoxos e complexidade na gestão do mosaico de unidades de conservação da área de proteção ambiental Cachoeira das Andorinhas - Ouro Preto/MG. GEOUSP Espaço E Tempo, 30: 90-106.

Schoener, T.W. 1987. The geographical distribution of rarity. Oecologia, 74: 161-173.

Simaika, J.P. \& Samways, M.J. 2012. Using dragonflies to monitor and prioritize lotic systems: a South African perspective. Organisms Diversity \& Evolution, 12: 251-259.

Sorgine, J. 2008. Salvemos Ouro Preto: a campanha em benefício de Ouro Preto, 1949-1950. Rio de Janeiro, IPHAN/COPEDOC.
Souza, M.M.; Pires, E.P.; Brunismann, A.G.; Milani, L.R. \& Pinto, A.P. 2017. Dragonflies and damselflies (Odonata) from the wetland of the Rio Pandeiros, northern region of Minas Gerais State, Brazil, with a description of the male of Archaeogomphus vanbrinki Machado (Anisoptera: Gomphidae). International Journal of Odonatology, 20(1): 13-26.

Souza, M.M.; Souza, B.; Pereira, M.C.S.A. \& Machado, A.B.M. 2013. List of Odonates from Mata do Baú, Barroso, Minas Gerais, Brazil. Check List, 9(6): 1367-1370.

The R Project for Statistical Computing (R Core Team). 2019. R: A language and environment for statistical computing. Vienna, R Foundation for Statistical Computing. https://www.R-project.org.

Vilela, D.S.; Koroiv, R.; Tosta, T.H.A.; Novaes, M.C. \& Guillermo-Ferreira, R. 2020a. Dragonflies and damselflies from the West of Minas Gerais, Brazil: checklist and new records. Biota Neotropica, 20(1).

Vilela, D.S.; Anjos-Santos, D.; Koroiva, R.; Cordero-Rivero, A. \& GuilhermoFerreira, R. 2020b. Revision of the genus Minagrion Santos, 1965 (Odonata: Coenagrionidae). Zootaxa, 4786(2): 176-198.

Vilela, D.S.; Ferreira, R.G. \& Del-Claro, K. 2016. The Odonata community of a brazilian vereda: seasonal patterns, species diversity and rarity in a palm swamp environment. Bioscience Journal, Uberlândia, 32(2): 486-495.

Wittwer, T.; Sahlén, G. \& Suhling, F. 2010. Does one community shape the other? Dragonflies and Fish is Swedish Lakes. Insect Conservation and Diversity, 3: 124-133. 